\title{
Unique case of acquired pulmonary arteriovenous malformation developed by calcific constrictive pericarditis
}

\author{
Toru Inami, ${ }^{1}$ Shinya Yokoyama, ${ }^{1}$ Yoshihiko Seino, ${ }^{1}$ Kyoichi Mizuno ${ }^{2}$
}

${ }^{1}$ Cardiovascular Center, Nippon Medical School Chiba-Hokusoh Hospital, Chiba, Japan

${ }^{2}$ Department of Cardiovascular Medicine, Nippon Medical School, Tokyo, Japan

\section{Correspondence to}

Dr Toru Inami,

t-inami@nms.ac.jp
To cite: Inami T, Yokoyama S, Seino Y, et al. BMJ Case Rep Published online: [please include Day Month Yearl doi:10.1136/ bcr-2012-008345

\section{DESCRIPTION}

A 58-year-old woman admitted to evaluate the symptoms of right-sided heart failure with slight ascites and peripheral oedema lasting more than

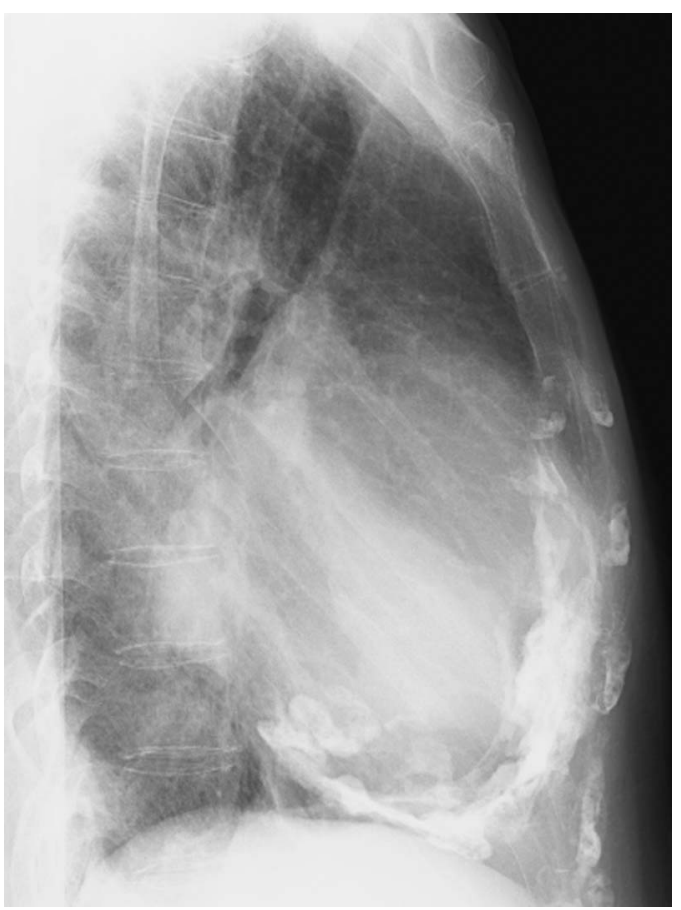

Figure 1 Chest x-ray (lateral view) showing extensive circumferential pericardial calcifications.
6 months. Her medical history revealed that she had been affected by pleuritis when she was 34 years old, and be diagnosed as constrictive pericarditis documented by right ventricular pressure tracings showing dip-and-plateau pattern at 50 years. The chest $\mathrm{x}$-ray (lateral view) demonstrated extensive pericardial calcifications from the anterior to inferior side of the heart (figure 1) and newly visible mass in distal site of right middle lobe of lung. The mass had not been detected 2 years before. Three-dimensional reconstruction of CT showed the pulmonary arteriovenous malformation (PAVM) that measured $42 \times 33 \mathrm{~mm}$ diameter in distal site of segment 5 (figure 2 and video 1 ).

PAVM was first reported by Churton in $1987 .{ }^{1}$ More than of PAVMs are congenital, and $60 \%$ of congenital have been associated with Osler-Weber-Render disease or herediary haemorrhaogic telangiecasia. Meanwhile many of acquired PAVMs are associated with the mitral stenosis, of which high pulmonary vascular resistance seems to contribute to the developing of PAVM. Killian reported that pulmonary hypertension was present more than $50 \%$ in constrictive pericarditis after cardiac surgery. ${ }^{2}$ Pulmonary artery pressure in PAVM is generally normal or low, so PAVM works as a function of low-resistance circuit to evacuate high blood pressure in pulmonary vascular resistance with constrictive pericarditis.

To the best of our knowledge this case is the first literature describing acquired PAVM secondary to constrictive pericarditis.

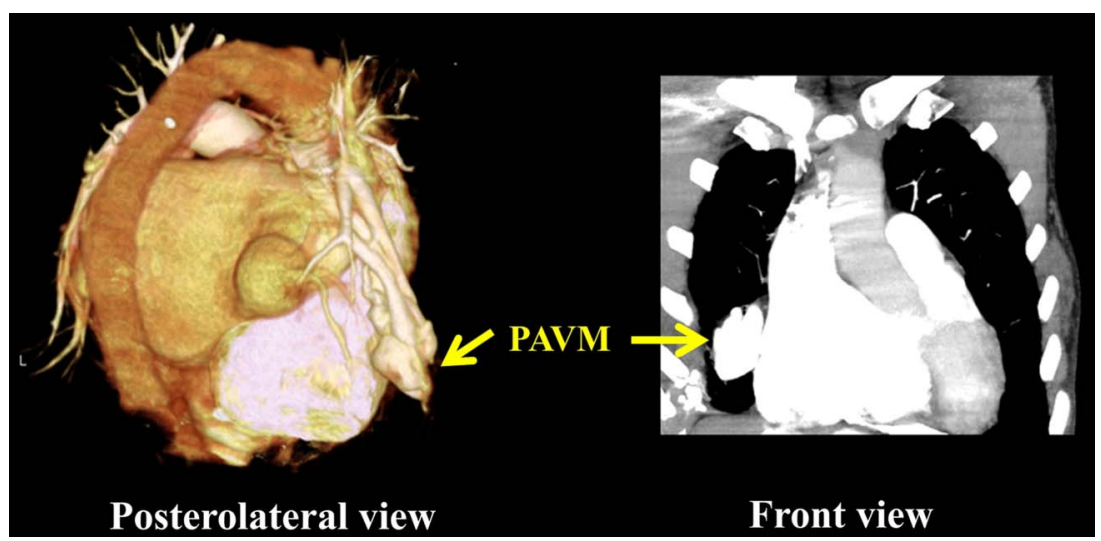

Figure 2 Three-dimensional reconstruction of CT illustrates the newly developed pulmonary arteriovenous malformation in distal site of right middle lobe of lung. 


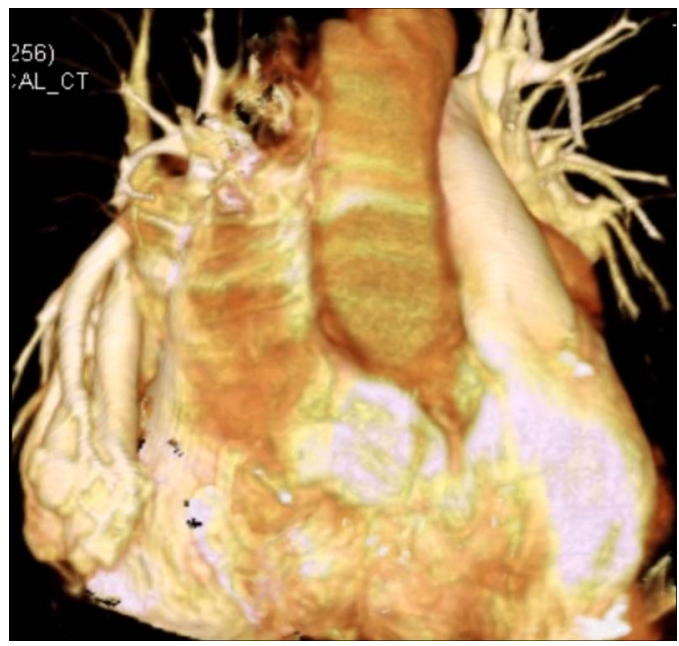

Competing interests None.

Patient consent Obtained.

Provenance and peer review Not commissioned; externally peer reviewed.

\section{REFERENCES}

1 Churton T. Multiple aneurysms of pulmonary artery. BMJ 1897;1:1223.

2 Killian DM, Furiasse JG, Scanlon PJ, et al. Constrictive pericarditis after cardiac surgery. Am Heart J 1989;118:563-8.

Video 1 The newly developed pulmonary arteriovenous malformation was animated in distal site of right middle lobe of lung.

\section{Learning points}

- Constrictive pericarditis could be a cause of acquired pulmonary arteriovenous malformation.

- The presence of pulmonary arteriovenous malformation (PAVM) should be evaluated in the constrictive pericarditis. This case describes a link between PAVM and constrictive pericarditis.

Copyright 2013 BMJ Publishing Group. All rights reserved. For permission to reuse any of this content visit http://group.bmj.com/group/rights-licensing/permissions.

BMJ Case Report Fellows may re-use this article for personal use and teaching without any further permission.

Become a Fellow of BMJ Case Reports today and you can:

- Submit as many cases as you like

- Enjoy fast sympathetic peer review and rapid publication of accepted articles

- Access all the published articles

- Re-use any of the published material for personal use and teaching without further permission

For information on Institutional Fellowships contact consortiasales@bmjgroup.com

Visit casereports.bmj.com for more articles like this and to become a Fellow 